\title{
Language and Gender Differences in Jordanian Spoken Arabic: A Sociolinguistics Perspective
}

\author{
Ahmad Mohammad Ahmad Al-Harahsheh \\ Translation Department, Yarmouk University, Irbid, Jordan
}

\begin{abstract}
Studying the differences between men and women's language has been the obsession of many sociolinguists recently. This study aims to investigate the gender differences between men's and women's language in Jordanian Spoken Arabic. It studies both genders' conversational styles and phonological variations. Twelve dyadic conversations (mixed and same-sex) were conducted at Yarmouk University (Jordan) each conversation lasted for $\mathbf{3 0}$ minutes. The theoretical framework for this study draws on sociolinguistics, Conversation Analysis and politeness theory. The findings of the study indicate that Jordanian women and men have different linguistics styles that distinguish their gender in conversations, and women are more linguistically conservative than men.
\end{abstract}

Index Terms - sociolinguistics, gender, men's and women's language, Jordanian spoken Arabic, politeness and conversation analysis

\section{INTRODUCTION}

Sociolinguistics studies the way people speak differently in different social contexts. It also gives reasons for why and how people speak differently (Holmes, 2006). Studying men and women talk has been the obsession of sociolinguistics research in the mid 1970s. Coates $(1998$, p.2) states that it is common in all societies that "the way men speak is held in high esteem, while women's ways of talking are compared unfavourably with men's"; she refers to these cultural beliefs as 'folklinguistics'. The old notion that women are chatterboxes has not existed nowadays, because different studies in different social contexts- in the workplace, in the television, in the classrooms ...etc- have proved that men speak more than women (Coates, 1998).

Cameron (1998, p.271) states that "gender is socially constructed rather than 'natural' " Simone de Beauvoir said "one is not born, but rather becomes a woman'. Discourse explains "the pattern of gender differentiation in people's behavior"; discourse makes this differentiation visible (Cameron, 1998, p.271). In addition, Judith Butler (1990), [cited in Cameron, D. (1998)], explains that masculinity and femininity can be defined by performing certain acts in accordance with the cultural norms. Furthermore, "men and women may use their awareness of the gendered meanings that attached to particular ways of speaking and acting to produce a variety of effects" (Cameron, 1998, p.272). Men and women are members of culture and they learn the suitable ways of speaking and a large set of gendered meanings that attached to different ways of speech; "they produce their own behavior in the light of those meanings" (Cameron,1998,p.281). This is true in Jordanian society as the social norms determine the men and women's speech. For example, in Jordanian society a woman should not use men's speech style because it is socially unacceptable. A woman should speak in a way that reflects her femininity.

The linguistic choices in any social interaction are influenced by the following social factors: first, the participants i.e. who is speaking and whom and the relationship between them or the social distance i.e. are they intimate or not, and the status scale i.e. are they superior or inferior to each others. Second, the social context of the conversation or the setting i.e. the place of the interaction will influence the kind of linguistic repertoire used. For example, in court sessions the type of language will be formal, but informal in cafés. Third, the topic of the interaction affects the linguistic choices; the language used in discussing an academic subject is different from that used in talking about everyday life conversations. Finally, the function of the interaction determines the type of linguistic repertoires used in an interaction, is the function of the conversation referential i.e. to give information or affective i.e. to express feelings (Holmes, 2008).

It is implausible to divorce language from society, as language can be only understood in its social contexts. In other words, the interpretation of an utterance out of its original context i.e. it is Okay, would be impossible, as it could be an agreement, disagreement or a continuer. There is a general agreement among sociolinguists that no two people speak the same, whether males or females; it is easy to know the social identity, sex, educational level, and region of someone from his/her speech (Holmes,2008 \&Wardaugh,2006).For example, people who live in Manchester pronounce /t/ as glottal /?/ when it comes between two vowels. However, Americans pronounce /t/ as /d/ when it also occurs between two vowels. Australians pronounce the word day, as die and News Zealanders pronounce dad as dead. It is worth mentioning here a funny situation, narrated to me by an Australian friend, an old British man visited Australia; in the airport the customs officer asked him" you came today?"(Today is pronounced as to die in Australian Slang) The British man answered angrily: No, I am not coming to die here, another Australian customs officer heard the 
conversation came quickly to the old British man telling him that "the customs officer asking you if you arrived here today and Australian pronounce today as to die.

The present study concentrates not only on the phonological and phonetic variations that manifest gender differences but also on the conversational strategies of male and female speakers in Jordanian Spoken Arabic (JSA). This study investigates same-sex and mixed-sex dyadic conversations.

\section{Gender and Sociolinguistics Studies}

Recent social dialect research focused on differences between men's and women's language in terms of pronunciation, morphology, syntactic constructions such as multiple negation, semantic and style (Holmes, 2008). Trudgill (1968) finds that in Norwich English males use more non-standard [n] forms than females who use[ng]. Labov (1966) also finds that, in New York City, the more people used post-vocalic [r], the more prestigious they are; women pronounce the post-vocalic [r] more than men. The majority of research on the differences between men and women's speech focused on phonetic features rather than conversational strategies. This study is distinguished as it focuses on gender differences within the interlocutors conversational styles, such as the function of the talk, conversational feedback, repetition, dominance in conversation solidarity and phonological variations.

Lakoff (1975) studies women's language in the USA. Lakoff (1975) characterizes the linguistics features of women's language as:

1- Lexical hedges or fillers (you know, sort of, well, you see)

2- Tag questions (she's very nice, isn't she?)

3- Rising intonation on declaratives (it's really good)

4- 'Empty' adjectives (divine, charming, cute)

5- Precise colour terms (magenta, aquamarine)

6- Intensifiers such as just and so (I like him so much)

7- 'Hypercorrect' grammar (consistent use of standard verb forms)

8- 'Super-polite' forms (indirect requests, euphemism)

9- Avoidance of strong swear words (fudge, my goodness)

10- Emphatic stress (it was a BRILLIANT performance)

Lakoff (1975) states that woman's language functions to express lack of confidence, uncertainty or tentativeness (Holmes, 2008). Lakoff (1975) argued that the use of hedging devices by women signal an evidence of their uncertainty, and boosting devices express their anticipations that the addressee may still unconvinced, so they need to supply another evidence (Holmes,2008). Lakoff's (1975) methods of collecting and analyzing data were artificial as she collected her data in a laboratory with a screen between the speakers. The results also were contradictory, because many sociolinguists noted that men used more tag questions than women did, and some others found that there were no gender differences (Holmes, 2008).

Based on different sociolinguistics studies, which carried on investigating the differences between men's and women's language, most sociolinguists have agreed that women used more standard forms than men who tend to use vernaculars. According to Holmes (2008), there are different reasons for why women use more standard forms. First, the social norms of a society that we expect women's behavior as a model (guardian of society's values), this will affect the language they use. In addition, women are more status- cautious rather than men. Women are alleged by a stereotypical expectation when they speak, whatever they say "can be used against them as an evidence of their deficiencies"(Holmes, 1985, p.25). Women also lack status in the society, so they "try to acquire it by using standard speech forms, and by reporting that they use even more of these forms than they actually do" (Holmes,2008,p.164). By using standard forms, women fulfill their own face-protection needs and those they talk to. On the other hand, men use vernacular forms because they relate it to "masculinity and toughness"(Ibid:p. 167). Other reasons why women use standard forms are that women were interviewed by male strangers and their sensitivity to contextual factors such as the topic raised during the conversation.

Labov (1966) explains that the use of non-standard forms is demonstrated by the norms of the vernacular subculture. Yet, the employment of Standard English is dominated by the manifest norms of the mainstream culture in society. Eckert (1998) studies the phonological variation of pronunciation in American English; she explains that accent gives information about the speaker's social identity such as class, age, ethnicity and gender. Eckert (1998,p.65) adds " the closer a person's speech is to the standard, the more difficult it is to tell where he or she is from; the closer to the vernacular, the stronger and more identifiable their regional or local accent". Indeed, people produce more standard pronunciation, as they move up the socioeconomic hierarchy (Eckert, 1998; Holmes, 2008 and Wardaugh, 2006).

In fact, "gender practices differ considerably from culture to culture, from place to place, from group to group, living at the intersection or all other aspects of social identity" (Eckert, 1998,p.66). This is true depending on the norms that organize the relationship between men and women in a certain society, i.e. in the Arab world in general and in Jordan in particular, people expect an appropriate linguistic style from a woman such as intonation, pronunciation, and vocabulary. Jordanian women are sometimes blamed because of their unusual use of pronunciation and vocabulary, because it is considered as a violation of the social norms of Jordanian society. Eckert (1998) and Holmes (2008) aver that women's language is more conservative than men's, because women are more status-conscious or polite and men are tough. This is true for Jordanian society where women are more status-conscious rather than men who supposed to 
be tough, because the social norms restrict the way men and women speak. For men, their speech should reflect their masculinity otherwise they will be accused that they are womanish.

Trudgill (1972) ${ }^{1}$ states that women are more conservative in using almost variables of pronunciation in Norwich, because women are excluded from the work place, and because they have fewer opportunities to secure their positions by being successful at work or other abilities; they find it essential to use the standard forms to enhance their positions. Eckert (1998,p.66) states that even in work place women need to use "standard language market" to do many 'white collar jobs' such as a receptionists, secretaries, flight attendants and hostesses; they are representing their organizations and earning living. Therefore, the more conscious use of standard language may make women more conservative than men based on the token "talking for success"(Eckert, 1998, pp.66-67). Eckert (1998) concludes that it is difficult to generalize that women are more linguistically conservative than men, but women's greater use of phonological variables to establish membership and status.

\section{Gender and Politeness}

Brown and Levinson (1987) maintain that there are three sociological factors to determine the level of politeness a speaker uses to an addressee: (a) relative power of hearer over speaker, (b) the social distance between speaker and hearer and (c) the ranking imposition involved during the Face-Threatening Act (FTA). They independently mention another factor which is the higher liking variable which affects choice of politeness. It is essential in "distinguishing an attack (insult) from an expression of admiration"(ibid.p.16). Brown and Levinson (1987, p.31) claim, "Women operate more positive politeness strategies to a higher degree, because they operate dense social networks". This hypothesis is related to Labov (1966) findings that women employ more prestigious dialect variables compared to men. This true in JSA as women are keen on protecting the other interlocutors' face by avoiding direct disagreement and producing more backchannels as a rapport strategy.

\section{Gender and Language in Jordan}

In Jordan, there are four recognized linguistic repertoires; namely Standard Arabic which is the official language of the Kingdom; it is the language of the courts, the media and official governmental department. Secondly, urbanized dialect which is deemed to be prestigious in Jordanian society, it is used in cities' centers. Fascinatingly, this dialect has been used by Jordanian young females whatever their regions are, because they consider this dialect as the most prestigious and the most favorable in the society; they use it to show themselves off. Third, the rural dialect which is spoken by people who are living in the rural and agricultural areas; it is different from the urbanized dialect in terms of pronunciation, vocabulary and grammar. Finally, the Bedion dialect is spoken by people who are living in the Eastern and Southern regions of the Kingdom.

Studying how men and women use language in interaction has been the obsession of many sociolinguists all over the world such as in the USA, the UK ...etc. However, few studies are carried out in the Arab world in general and in Jordan in particular. Al-Ali and Arafa (2012) studied the phonological variations of Jordanian speech sounds; their samples consist of two groups: school students and university students. They ask them to tell the story depicted in 32 pictures presented in Microsoft PowerPoint instead of the written forms of words; they find that gender and educational settings affect the linguistic variations. Malkawi (2011) studied how men and women speak differently in three social occasions: gladness, consolation, thankful after banquet and farewell. She used a questionnaire to elicit the participants' answers toward these social occasions, she concluded that women use urbanized dialect to show off, and they think that it is the prestigious dialect in Jordanian society. Al-Harahsheh (2012) finds that women have longer period of silence rather than men do, especially in mixed-sex conversations as the social norms in Jordan in favour of a silent women rather than the talkative one.

This study is distinguished in terms of its purpose as it focuses on gender differences styles and phonological variations. It is also the first study, to my best knowledge, that tackles this crucial issue. It is also methodology, that is to say, the data were collected from real life situations, and the participants were grouped in same-sex, and cross-sex conversations. Also, this study is different and original, because it does not on focus on phonological variations but also on conversational styles and strategies practiced by men and women in conversations. In terms of solidarity, there were grouped into friends and strangers to show the differences in language style use.

\section{Questions of the Study}

There are many intriguing issues in sociolinguistics that still unstudied in Jordan, such as how men and women use language in different social settings. This study is also original and significant in terms of methodology, theoretical framework and analysis. This study is devoted to answer these crucial questions:

1-Are women more linguistically conservative than men? I.e. in using linguistic variables such as pronunciation and vocabulary

2-Do women operate more politeness strategies than men?

3- What are linguistics and conversational strategies practiced by men and women in conversations?

\section{Methodology}


The sample of the study consisted of 12 dyadic conversations which were videotaped at Yarmouk University (IrbidJordan) in 2010. The age range of the participants was between 19-26 years. The conversations took place on campus in an office; a video camera was positioned in front of the participants and they were sitting in front of each other and they were asked to talk about any topic they wish; two topics were suggested for them as an assistance in case they did not find a topic to negotiate such as the university life and the nature of course they were studying. Each conversation lasted for 30 minutes. The conversations were categorized as: two dyadic conversations between females stranger; two dyadic conversations between female friends; two dyadic conversations between male friends, two dyadic conversations between male strangers, two dyadic conversations between male-female strangers and two dyadic conversations malefemale friends. These conversations are also categorized as same-sex, and cross-sex conversations.

\section{Theoretical Framework}

Sociolinguistics, Politeness theory and Conversation Analysis are together employed as a theoretical framework for the current study since all of them concern in how interactants use language in everyday conversation and in social settings in general. Conversation Analysis (CA) is "the systematic analysis of the talk produced in daily situations of human interaction: talk-in-interaction" (Hutchby \& Wooffitt, 1998, p.13). Therefore, the beneficial framework for this kind of study should be a combination of sociolinguistics and CA.

\section{ANALYSIS AND DISCUSSION}

Gender differences in the language used between men and women are inextricable. Therefore, highlighting these differences requires a multifaceted theoretical framework and the discussion should include the social factors that affect the relationship between the interlocutors such as the function of the talk, the participants, solidarity and the topic of the talk. Examining the data collected scrutinizingly, I found some differences in their linguistics styles and conversational strategies.

\section{Function of the Talk}

When analyzing the function of the talk, it is essential to distinguish between the affective (personal) meaning and the referential (informative) meaning (Holmes, 1998). Holmes (1998, p.463) supposes that "women tend to focus on the affective of an interaction more often than men do". In other words, women mainly tend to expresses their feelings when communicating with each other and even with males. In cross-sex conversations, women tend to be more sensitive to the information that has been conveyed in their talk. The findings of the study approve this assumption. In extract (1) below a woman was explaining her embarrassing and her tension when she was presenting a topic in front of 100 students, because all students were gazing at her and some of them were looking mistakes to criticize her. She therefore showed her feelings to her friend (male). However, the man's answer was referential rather than affective "Do you ask yourself why?)Again his response in the last line was also referential "No, I do not allow anyone to talk in the lecture."While she was talking affectively, he was trying to give a logical interpretation to what she said.

\section{Extract No.(1): [M-F friends]}

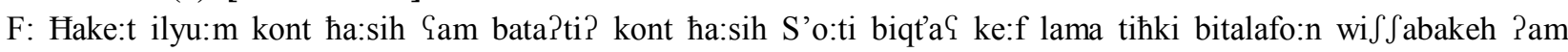

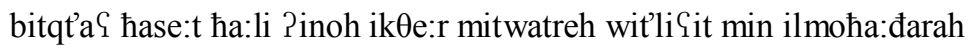

M:t'ayib sa?alti ha:lik le: $\int$ ?

F: aw Pana mitwatreh bitđal fikreh Pinoh ke:f bidi Pawaqif qida:m me:t t’a:lib ya Sni ke:f Pinak bidak itwaqif qoda:m

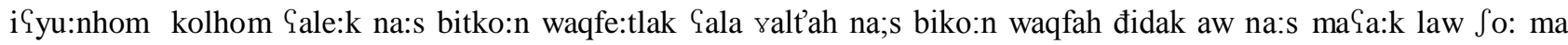

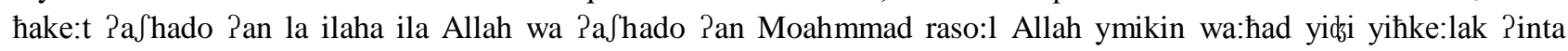

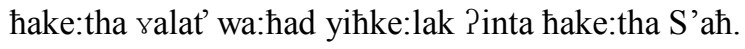

\section{M: la? ?ana bimoha:đarah bismahi lahada yihki.}

\section{Translation in English}

F: I was talking today, I feel that I was stammering, I felt my voice was cutting the same as you are talking on the phone and the network is down. I felt so high-strung and I left the lecture.

M: Okay, did you ask yourself why?

F: While I am tense, I am thinking of how can I stand in front of 100 students, that is, how can you stand in front of students who are all gazing at you? There are some people who are waiting for you to make mistake, and there are some are sympathizing with you. Whatever you say even if you say there is no God but Allah and Mohammad is the messenger of Allah, one of them may tell you that you say it wrongly or another may tell you it is right.

\section{M: No, I do not allow anyone to talk in the lecture.}

\section{Conversational Feedback}

Conversational feedback is another important factor in distinguishing gender differences in the language used by men and women in JSA. Women are considered as cooperative conversationalists; "they provide more encouraging feedback to their conversational partners than men do"(Holmes, 2008, p.309). In other words, women tend to produce more positive feedbacks to save the face of the other participant. For example, in JSA, women tend to produce more continuers, agreement, repetition of the utterances of their conversational partner, minimal responses, and they produce boosting and hedging devices as encouragement and politeness devices such as words like "By God, Cool, so nice, amazing, the exclamation particle Wallah (by God), (t'ayib) Okay, Ya:y, Yeah ...etc". The function of using minimal 
responses is "to support the speaker and indicate the listener's active attention" (Coates, 1998A, p.237). However, men tend to be more competitive and less supportive than women. Therefore, women tend to avoid direct disagreement with men, and they show agreement with men and women in conversation, because the "goals of the interaction are solidarity stressing-maintaining good social relations" (Holmes, 2008, p.309), and this is what women are keen to achieve during conversation.

It was observed that in JSA, women and men tend to avoid threatening the face of the other partner, especially in mixed-sex or same-sex conversations between with those whom they do not like have solidarity. In extract (2) below, F1 said that, "she does not like other females to criticize her and she does not an arrogant woman who has nothing and she likes to be honest with her girlfriends." On the other side, F2 produced positive feedback utterances such as "Yeah, like me" with rising intonation, and the continuer "yeah" as an agreement and encouragement strategies for F1 to proceed in her speech. She also attempted to save the face F1. Again, F2 were keen to produce agreement utterances for F2 after each topic raised by her, for instance in the line before the last F1 said, "I offer you the same as you offer me". From another angle, F2 also produced polite responses as a way to show her gratitude to F1 who shared her same opinion, such utterances produced by F1" yislam tomik ya Rana" (Oh! Rana, you are extremely right).

It is observed that women who do not have intimacy tend to exchange compliments to express solidarity, evaluation, praising, admiration and appreciation for each other's (Holmes, 1998A). It was observed that the conversation was so active to a degree that it was hard to detect period of silences (especially in this conversation). This proves the notion that in JSA, women tend to produce countless positive politeness devices for each other's rather than men.

\section{Extract (2) [Females Stranger]}

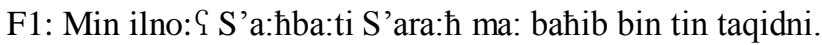

F2:?ah zaiyi

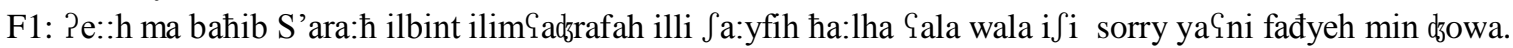

F2: ?ah

F1: bnafis ilwa?it ?inoh bahib ađal maS ilbint moxliS'ah.

F2: ?ah

F1: Ma anS' adim fe:ha ma anxadi $\mathrm{C}$ fe:ha, iSrifti keef Cali?

F2: ?ah

F1: bahib Pinoh yiko:n fi ixla:S' taba:dol hob ha:I keefik

F2: Zai ma ?aYt'i:ki ti't'e:ni

F1: yislam tomik ya Allah ya Rana San dzad yimkin inxadaCit fi: banat aw heeka.

F2: fe:h bildza:mSah

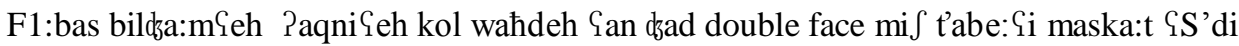

F1: ?ah

\section{Translation in English}

F1: Frankly, I am a person that I do not like a girl to criticize me.

F2: Like me.

F1: Pe::h Frankly, I do not like the arrogant girl who always shows herself off, and sorry she is nothing. That is, she is has nothing.

F2: Yeah

F1: At the same time, I like to be honest with a girl.

F2: Yeah

F1: I do not like to be shocked, to be cheated from her, you know?

F2: Yeah

F1: I like to have honesty, reciprocal affection

F2: I offer you the same as you offer me.

F1: You are right, Oh God, Oh Rana, I really was cheated by some girls and like

F2: There are at University.

F1: But at university they are hiding behind masks, really they have double-face, unusual masks, you mean?

F2: Yeah.

F1: I swear by God, it is something, really I do not know. I am from those who like to conceal things and I am so sensitive. So, my big family eases this thing.

F2: That it is.

\section{Dominance in Conversation}

Another observation in mixed-sex conversations, women tend to initiate more topics to maintain the mainstream of conversation and to break silence. This leads to the following assumption that women dominate conversations because they initiate more than men, thus they direct the conversation in the way they like. However, some sociolinguists think that dominance is correlated with interruption in conversation, but I think the more an interlocutor initiates topic, the more s/he dominates the conversation. In the data analyzed, women initiate more than men in mixed-sex conversations 
whether the interlocutors have intimacy or solidarity or not. Extract (3) is an illustrative example on dominating the conversation by a woman. To maintain the mainstream of conversation, the woman tended to initiate more topics respectively. For example, in the first line she asked the man "when will he graduate?", then in line three, she initiated again "when will you complete?"After that, she repeated the man's answer in line 4. Again, in the line before the last, she initiated an utterance in which she showed her feeling toward him that she wished he will never come back again to university i.e. to pass and not be obliged to stay for another semester.

Extract (3) (M-F Friends)

F:?imta Xire:ds?

$(0.7)$

M: Pana xire:dz ilfaS'il ha:đ

F: Kam bitxaliS'?

M: 19 wahad biko:n ?a:xir yu:m illi bildza:m $9 a h$

F:19 wa:had bitxalis' imtiha:na:t.

$(0.4)$

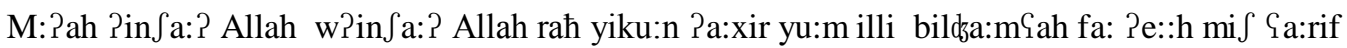

F: [ Pinfa:? Allah $]$ ya:rab ma tirdzaSilha: heh heh heh.

M: mi $\int$ rah Pardzaৎilha ho: ilmaka:n rah Piloh đikraya:toh fa

F: ?a:h

Translation in English

F: When will you graduate?

(0.7)

M: This semester

F: When will you complete?

M: 19 January is the last day for me at university.

F: You finish exams on 19 January?

(0.4)

M:Yes, God willing, God willing it will be the last day for me at university ?e::h I do not know

F: $\left[\begin{array}{l}\text { that } \\ \text { God willing }\end{array}\right]$ will never come back to it heh heh heh

M: I will not come back to it, but the place has it memories.

F:Yeah

\section{Repetition in Conversation}

Prepetition is an observable conversational style in JSA. According Johnstone (2008) there are three types of repetition in conversation: Alliteration, using words starting with the same sounds; parallelism i.e. repeating grammatical structures and Chiasmus for switching the orders of elements. Johnstone (2008) also state that interlocutors tend to repeat themselves and others for different purposes, such as "backchanelling " to show that the interlocutors are listening and understanding what has been communicating. In addition, repetition is used to solve problems in conversation i.e. self-correction and other's correction. It can also create a cohesive relationship among sentences and utterances. One of the most significant functions of repetition is to signal rapport between the interlocutors (Johnstone, 2008).

The findings of the study indicate that in JSA, women tend to produce more repetitions than men in conversation, whether in same-sex or mixed-sex conversations. In extract (4) below, in the first line, the woman initiated a new topic, she asked the man about how he spends his leisure times. She asked him, "What do you do? Where do you go in your leisure time?" She repeated and corrected herself in the second question, she repeated the question in another way "Where do you go in your leisure time?" Thus, repetition here is functional, and it aims to explain what has been said in the prior question.

In addition, she attempted to get the man involved in the conversation by uttering "You may spend most of your time on the Internet?" She also repeated the same utterance as a repairing strategy in the fourth line. She used a tag question "right?" as a facilitative strategy for the man to get him involved in the conversation. The man also used repetition strategies on words level such as" prominent prominent", "Like like ", and on the utterance level "a normal life a normal life." The man tended to paraphrase what he said in the prior utterance to make sure that the female is following him and understanding what he is talking about. For example, he uttered the following utterance "in the training course that I participated in, I participated in a training course".The function of this repetition (I participated in a training course) is to emphasize what he said in the prior utterance.

Again, the woman repeated the utterance "to be behind the scenes" to make sure that the man understood what she said in the prior turn. The man also repeated the same utterance "to be behind the scenes". This repetition functions as a backchannel to show that he is listening and understanding what she said.

Extract (4) [ F-M Friends] 


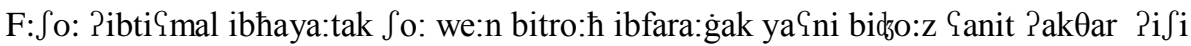

$\mathrm{M}: \mathrm{Ke}: \mathrm{f}$ ?

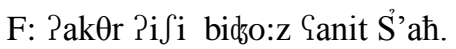

M: fe:h wallah fe:h ilnit bo:xið mini waqit la ba?is fe:h mara:t bat'laৎ maৎ PiS'ha:bi bat'laৎ Canit bi?awqa:t

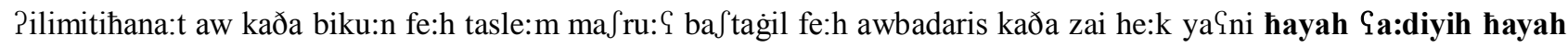
Ga:diyih zai zai hana:s ৎa:yi $\int$ ma fe: $\int$ Pi $\int i$ momayaz.

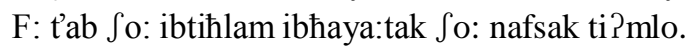

M:ha:đ isso?a:l kama:n Pinsa?altoh bidawrah illi $\int a$ arakit fe:ha qabil fatrah ?i Sa:rakit ibdawrah ke:f tintidz radio Palinternet

F: ?ah

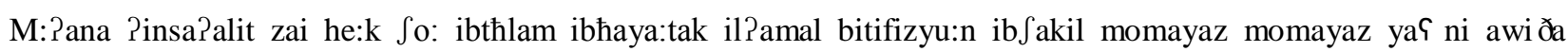
? intarakli ilmadsa:l bafo:t bimadza:1 iltaS'we:r taS'we:r iltifizyu:n.

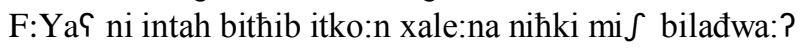

M: La?

F: mis bilađwa:? yas ni.

$\mathrm{M}: ?$ ah

F: mmm

M: min wara:? ilkawale:s.

Translation in English

F: What do you do? Where do you go in your leisure time? You may spend most of your time on the Internet?

M: What?

F:You may spent most of your time on the Internet, Right?

M: Yeah, (by God) the Internet take a considerable time like, but sometimes I go out with my friends, we go to the Internet café, in the exams time and when I have to submit a project or something, or I study like this, like it is a normal life a normal life I live like like other people, I do not have a distinguished thing.

F:Yeah, okay, what is your dream in life? What do you wish to do?

M:I was asked this question in the training course that I participated in; I participated in a training course, how to broadcast a radio on the Internet.

F: Mmm

M: I was asked this question like what is your dream in life? Practically, working in the television in a prominent prominent way like if I had the chance I will work in the Imaging field Imaging TV.

F: You mean you would like to be behind the scenes, let us say.

M: No

F: Like to be Behind scenes

M: Yeah

F: Mmmm

M: Behind the scenes

Solidarity

Solidarity refers to how well we know someone; the more intimate the relationship between the interlocutors, the higher the solidarity will be between them and vice versa. In their interaction, women tend to focus on the feelings of the person they are talking to (Holmes, 1998). They show their sympathy and encouragement to their partner in the talk. The findings of the study showed that women have cooperative nature in mixed-sex conversations. They tend to interact sympathetically with men especially when men have psychological problems or they are in a bad temper. In such conversations, women tend to secure agreement, show signs of attention to the man's face. In extract (5) below, the male seemed frustrated because he had a trouble with the lecturer of one courses, and he was worried that the lecturer may fail him in that course, so he would not graduate this semester. He tended to show his indifference about the subject and refused to show apology for the lecturer. The female on the other hand showed sympathy with the man's case and she asked him to go to the lecturer and to apologize for him; and she is keen to attend the man's graduation ceremony and to write him a memory in his graduation booklet. At the beginning, the man tried not to tell the female about the real reason for his frustration, this can be understood from his utterance "what? Nothing", and the ironic utterance " because of Ids ru: $\hbar "$ (an ironic utterance said when someone tries to hide his frustration). It can be observed that the woman tried to elicit information.

\section{Extract (5), [M-F Friends]}

M: ds ad wallah qarfa:n.

$\mathrm{F}: \mathrm{Min} \int \mathrm{u}:$ ?

M: Ha wala ? i $\int$ i

F: $\int$ u: illi $S$ 'a:yir maS a:k?

M: Unheard

F: La: $\int$ ? 
M: ؟ a $\int$ a:n idbru:
F: Doko:r me:n
M: dakto:r Mousa isle:mi
F: le:h
..
F: ? e: $\int$ yaৎ ni yilwe:lak ? iðnak yehamlak ma:dih

M:Hi Ha:I w? iða ? it? axart ho: ? ay ma:dih hasa؟ fe:ha xalaS' fe: $\int$ wahadeh 21 aw 24 ra:hat ma:dih hasa؟

F: wa la $\int \mathrm{i}$

M: ha:đah illi xa:yif minoh

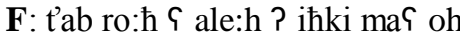

F: La Hamzih bidna niћđar taxds ak $\uparrow$ a $\theta$ a:ni bidna: $\int$ inđal nistaneh lil? awal

M: ho inda:ri $\int \mathrm{u}$ : bidi ? asaweelko ha:đ illi S'a:r baৎ de:n ? ana $\uparrow$ a i? awal ? aro:ћ ? ahđar haflih taxarods ? w daftar bide: $\int ?$ as aliq.

F: t'ab ? ana ke:f bidi ? ktoblak.

M: XalaS' ? okobe:li ؟ la ilie:me:l tahni? ah baktob dafter taxaro:ds $\uparrow$ ala ilFacebook

? aw ba९ t'e:h ? iya:h ? aw 9 alqo: biqisim ? insi.

F: ? e: $\int$ ha:đ wađৎ ak min il? a:xir ? intah mokta? ib.

Translation in English

M: Really, by God I feel frustrated.

F: For what?

M: What? Nothing.

F: What happened to you?

M:Unheard

F: Why?

M: Because of idzru: $\hbar$ ( a phrase used ironically when someone tries to hide his sad feeling)

$\mathrm{F}$ : Who is the doctor?

M: Dr. Mousa Ismle:man

F:Why?

F: What do you mean by giving you a lesson, he will fail you the course.

$\mathrm{M}$ : That is it, there is no course to fail in.

F:Nothing.

M: This is what I am worried about.

F:Okay, talk to him.

F: No Hamzeh we would like to attend your graduation ceremony in second semester, we do not like to wait for the first semester.

M:I do not know, what shall do for you? I will attend the ceremony in the first semester and I will never hang the graduation book.

F: So, how can I write a memory for you?

M:You can write on my wall on Facebook

In extract (6) below, the two females are studying English language, and they were fourth year students. Interestingly, both females did not only use urbanized dialects but they also employed code-switching and borrowing too much in the conversation. The reasons behind this are: first, speaking English is prestigious in Jordan, because it is considered as a second language, and it is highly demanded in many jobs nowadays. Both females' linguistic repertoires are affected by English language concepts and terms. Second, both females tended to borrow English words albeit their synonyms are lexicalized in Arabic. For instance, ? a fi:h mifil ilmadrasah careless (yes like in the school is careless). The adjective careless is lexicalized in Arabic; its synonyms is la mobali. Another example uttered by the other female, ?o: fi: $h$ far? bithisi fi:h gap be:n ilmadrasah wa dirasit ilmadrasih ( you feel that there is a difference, a gap between the school and its study. Other English words were also borrowed in this conversation such as start, magic, writing accounting, In addition, in urbanized dialect the /q/ ق sound, voiceless uvular stop, is pronounce as /P/, voiceless glottal stop. Therefore, both females pronounce it as /? /. We can see other examples in words like wa ? it (time), bit ? o:li (you said), bit? dar (you can), bitla? $i: n i$ (I will be) ... etc.

In addition, both women show many positive politeness strategies such as producing more positive feedback or encouragements to save each other's faces. Even when they interrupt each, this interruption was positive and it functions to encourage the train of the other participants thought. This proves the hypothesis proposed by Holmes (1998) that "women tend to use linguistic devices that stress solidarity more often than men do", especially in stranger same-sex conversations.

Extract (6): (Two female's stranger) 
F1: Kam ? oxit 9 indik?

F2: Waћdih ? o $\theta$ ala $\theta$ ? awlad.

F1: ma $\int$ a:? Allah ? into: small ? i hna big huge family, family.

F1: How many sisters do you have?

F2: One and two brothers.

F1: God willing, you are a small family, we are a big huge family, family.

In this extract, F1 code-switches into English; the purpose of code-switching here is to show off and to show herself as prestigious as well as to show solidarity because both speakers are studying English Language. The rest of the conversation is full of code-switching by both females. To conclude, in conversations between females strangers, women tend to use urbanized dialect and even code-switching especially those who study a foreign language. However, those who do not study a foreign language, they do not code-switch, but they only use urbanized dialect.

In conversation between females' friends, the findings of the study show that women who have intimacy tend to be ease during the conversation; they use both mixed of urbanized rural dialects. This indicates that intimacy plays a pivotal role in selecting the linguistic style and dialect. Both participants think that they are free from the social barriers, they therefore speak comfortably and they are away from refinements of their speech as they do when talking to strangers. The findings of the study agree with Cameron's (1998) that women tend to pay considerate attention to each other's faces to seek for good Social connection rather than status, whether the speakers are friends or strangers. Women also gain status by showing the suitable degree of concern for others, and lose status by showing "less concern for others and too much for herself "(Cameron, 1998, p.280).Consider extract (7) below.

\section{Extract (7), [Females Friends]}

F1: bas ana daxaltuh

F2: me:n ? ili 9 a:rđ

F1:? il? ahil yas ni

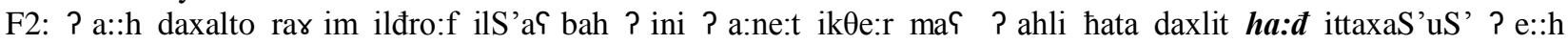
bis itbar ? inu: taxaS'uS' S'as ob ? w mis lilbana:t ibra? ihom yas ni.

F1:But I study it.

F2: Who opposed you.

F1: My family.

F2: Yes, Regardless the difficult circumstances, the I suffer a lot with my parents, but I study it. They think that this specification is hard and should be only for males not females.

\section{Phonological Variations}

This section focuses on phonological variations, as they are crucial in distinguishing the gender differences between men and women's languages. The findings of the study show that women are more considerate and conservative to the phonological variations than men are. That is to say, they tend to use the urbanized pronunciations of some letters to show politeness and to distinguish themselves that they are urbanized, prestigious and educated. In extract (8) below, the female is asking the male about his refusal in participating in the Student Union's election at university. Actually, the female used the urbanized form of Jordanian JSA. This can be evident from words like ha:d (this). There are three forms of the demonstrative pronoun this in JSA, the urbanized form ha:d, the rural form ha:d, and the Bedion form ha:ð. However, the Standard Arabic form is ha:ða. She also used the Standard Arabic expression "bidfa $S$ ak lil ? amam $?$ aw bishabak lilxalf" (Does it push you forward or backward? However, the male used vernacular forms such as the demonstrative pronoun $h a: đ$.In addition, he uttered other vernacular forms like bađal maћali ( stay in my place). Yet, the urbanized form is bađal makani. Interestingly, the atmosphere of the conversation affects the male's linguistic choices, as he tried to code switch between vernacular and urbanized dialect. For example, he uttered the urbanized

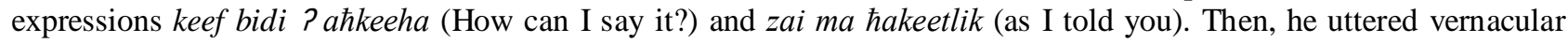
forms like ? aso:lif (was talking), lama babqa qa: $\varsigma$ id mas ? i sabab (when I was talking to my friends).

\section{Extract (8) [ F-M strangers]}

F: E::::h bit $\int$ o:f ? inoh ha:d ? i? is i Sah wala $r$ alat' bidfas ak lil? amam ? aw bishabak lilxalf.

M:? e::::h ha:đ ? ili? $\int$ i $?$ :::h 9 a::di wasat' ya 9 ni (0.3) la hou bidfaS ani lil? amam wa la ? ila ? ilxalf (0.2), bađal

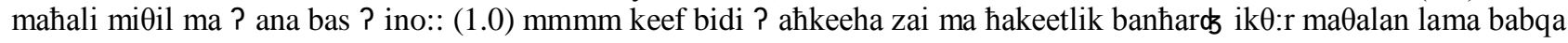
qa:؟ id mas is abab lama ? aso:lif ? is i (0.2) kolhom ? inibahom 9 ali babatil ? aso:lif.

$(0.6)$

F:? inta ibtodros inoble:zi, S'ah?

M: S'ah

F: Ya؟ ni momkin fi ilmostaqbal itko:n ? e::h moৎ alim ? osta:ð mmmm ? osta:ð?

M: Mmmm ? a::di mmmm ma ? indi ? e::h ma:ni؟

F: Ma ho: ilkol raћ yiko:n intiba:hoh $\subseteq$ ale:k, kol it'tola:b yimkin yidzi mode:r yimkin yidzi mo $\int$ rif momkin ilkol rah yiko:n intiba:hoh $\uparrow$ ale:k.

M: ? e::::h

F:Intah momkin tirtaqi momkin taxod ? in $\int$ a:ৎ Allah master ? o dokrorah witS'e:r ibmawđi؟ ? e::::h ya؟ ni ilkol rah yiko:n intiba:hoh $\uparrow$ ale:k mi $\int$ bas iS ’ ha:bak heh heh heh heh 


\section{Translation in English}

F: Do you think this is the right or wrong? Does it push you forward or backward?

M: This thing is Okay, normal, that is (0.3) it does not push me forward or backward(0.2) I stay in my position like I, but it is (1.0) mmmm how can I say it? I feel so embarrassed, for example when I am talking about something to my friends $(0.2)$ when they all give me attention I stop talking.

(0.6)

F: You are studying English, right?

M: That is right.

F:That is, you may be a teacher in the future, ? e::::h, a teacher mmmm a teacher ?

M:Mmmm it is Okay mmmm I have no objection.

F: The attention of everybody will be on you, may be all students, the headmaster, the supervisor, the attention of everybody will be on you.

M: ? e::::h

F: You may get a promotion, you may get a master or a PhD God willing, and you will be in a position ? e::::h , that is, the attention of everybody will be on you, not only your friends heh heh heh heh.

It is clear that the male tried to use the urbanized dialect to attract the females' attention and to show himself off as an educated and urbanized young man. From my experience as a sociolinguist, the majority of Jordanian young men (i.e. those who studies at universities), regardless of their regions, tend to use the urbanized form when talking to female students rather than vernaculars. The tendency behind this is that they think this dialect is the most prestigious and preferable for women; the one who speaks it is urbanized, educated, diplomatic, acceptable or may be romantic.

The same is true for females who come from rural regions; the majority of them use the urbanized dialect, as it is the acceptable or the unmarked linguistic form of females' speakers. However, the rural or vernacular dialect is marked and unacceptable from females. In addition, the urbanized dialect reflects their femininity more than the rural dialect. In some cases, young female students are blamed by their peer students when using rural or vernaculars on the campus, as they look at them as unurbanized and uneducated. Amazingly, women who come from rural regions use vernaculars at home, with family members and females whom they have intimacy even on campus, but they use urbanized dialect when talking to stranger males and females, to protect their facial needs as women are more status-cautious rather than men. Al-Wer (1991) states that young and well-educated Jordanian women who have contacts outside their communities accommodate to the new community's linguistic variants more than old and less educated women, because the latter are more exposed to local network pressure.

\section{CONCLUSION}

After reviewing the findings of the study, it is clear that the distinction between men and women's language in an indexical task. The study shows that there are distinguished differences between women and men's linguistic styles. Women tend to avoid direct disagreement, and they tend to maintain the social rapport with the other interlocutor. In addition, they tend to produce more facilitative strategies to get the other interlocutor involved in the conversation, so they are professional conversationalists and more cooperative than men are. Further studies are encouraged to investigate the differences in prosodic features such as intonation and pitch. The study found that women are more conservative than men in conversations, as they employ more politeness strategies than men do.

\section{APPENDIX}

The Phonemes of Spoken Jordanian Arabic

?: voiceless glottal stop \&

B: voiced bilabial stop ب

T: voiceless dental stop. ت

$\Theta$ : voiceless inter-dental fricative. $ث$

3: voiced palatal affricate ج (Jordanian Arabic)

db: fricative voiced alveolar ج (Standard Arabic)

$\hbar$ : voiceless pharyngeal fricative $\tau$

$\mathrm{X}$ : voiceless velar fricative $\dot{\tau}$

D: voiced dental stop

ð: voiced inter-dental fricative ذ

r: alveolar tap J

z: voiced dental fricative $j$

$\mathrm{s}$ : voiceless dental fricative

$\int$ : voiceless palatal fricative

t 5 : voiced palatal fricative

s': voiceless fricative alveolar

t': stop voiceless emphatic

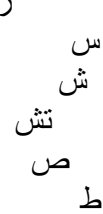




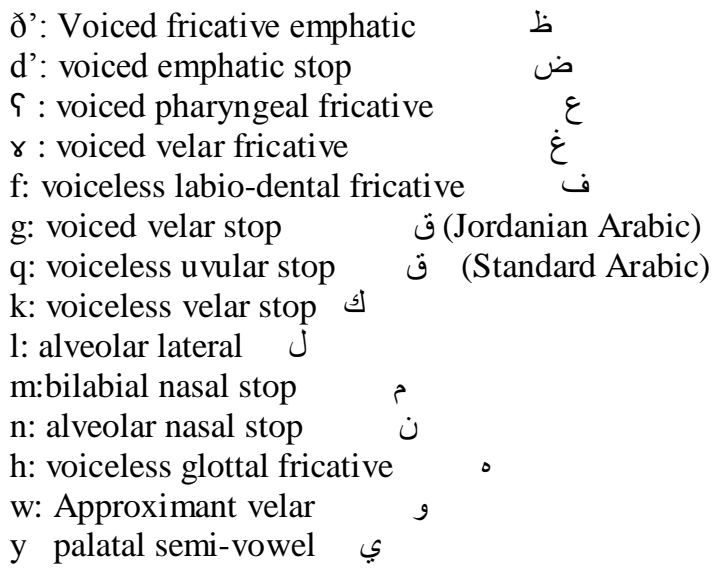

\section{Vowels:}

\section{Long Vowels}

I: high front

A: low back

$\mathrm{U}$ : high back

E: mid front

O: mid back
Short vowels
I high, front
A low, back
U high back
E mid front
$\mathrm{O}$ mid back

\section{REFERENCES}

[1] Al-Ali, Mohammad Nahar. (2012). An Experimental Sociolinguistic Study of Language Variation in Jordanian Arabic. The Buckingham Journal of Language and Linguistics Volume, 3, pp 207-230.

[2] Al-Harahsheh, Ahmad M. (2012) The Perception and Practice of Silence in Australian and Jordanian Societies: A Sociopragmatic Study. PhD dissertation. Western Australia: Edith Cowan University.

[3] Al-Wer, E. (1991). Phonological variation in the speech of women from three urban areas in Jordan. PhD dissertation. UK: University of Essex.

[4] Brown, Penelope and Levinson, Stephen. (1987). Politeness: Some Universals in Language Usage. Cambridge: Cambridge University Press.

[5] Cameron, Deborah. (1998).Performing Gender Identity: Young Men's Talk and the Construction of Heterosexual Masculinity. In J. Coates (Ed.), Language and Gender: A reader (pp. 270-284) Oxford: Blackwell Publishers.

[6] Coates, J. (Ed.). (1998). Language and Gender: A Reader. Oxford: Blackwell Publishers. Eckert, P. (1998). Gender and Sociolinguistic Variation. In J. Coates (Ed.), Language and Gender: A reader (pp. 64-76). Oxford: Blackwell Publishers.

[7] Coates, J. (1998A).Gossip Revisited: Language in All-Female Groups. In J. Coates (Ed.), Language and Gender: A reader (pp. 461-483) Oxford: Blackwell Publishers.

[8] Holmes, Janet. (1985). Sex Differences and Miscommunication: some Data from New Zealand. In John B. Pride (ed.). Crosscultural Encounters Communication and Miscommunication.River Jiene Public Publication: Melbourne.

[9] Holmes, Janet. (1998). Women's Talk: The Question of Sociolinguistic Universals. In J. Coates (Ed.), Language and Gender: A reader (pp. 461-483) Oxford: Blackwell Publishers.

[10] Holmes, Janet. (1998). Complimenting -A positive Politeness Strategy. In J. Coates (Ed.), Language and Gender: A reader (pp. 100-120) Oxford: Blackwell Publishers.

[11] Holmes, Janet. (2008). Introduction to Sociolinguistics ( $3^{\text {rd }}$ Ed).Pearson Longman: New York.

[12] Hutchby, I., \& Wooffitt, R. (1998). Conversation Analysis: Principles, Practices and Applications. Cambridge: Polity Press.

[13] Johnstone, Barbara. (2008). Discourse Analysis $\left(2^{\text {nd }}\right)$. USA: Blackwell Publishing.

[14] Malkawi,Abeer H. (2011). Males' and Females' Language in Jordanian Society. Journal of Language Teaching and Research.Vol.2, No.2 pp, 424-427.

[15] Labov, William. (1966). The Social Stratification of English in New York City. Washington, DC: Center for Applied Linguistics.

[16] Trugdill, Peter. (1968). Sex and Covert Prestige. In Coates, Jennifer (Ed.) (1998). Language and Gender: A Reader. Oxford: Blackwell Publishers.

Ahmad Mohammad Ahmad Al-Harahsheh is an Assistant Professor of Applied Linguistics. He is teaching linguistics and translations courses for graduate and undergraduate students in Translation Department at Yarmouk University-Irbid, Jordan. His research interests include Sociolinguistics, Pragmatics, Discourse Analysis, Critical Discourse Analysis, Political Discourse, Translation Theories and Mass Media Translation. 